\section{Military Technical College Kobry El-Kobbah, Cairo, Egypt}

\section{$8^{\text {th }}$ International Conference on Electrical Engineering \\ ICEENG 2012}

\title{
Investigation Techniques in Ground Water
}

\author{
By \\ Ashraf E. M. Mohamed \\ The Western Coast University \\ American International University \\ USA
}

\section{$\underline{\text { Abstract: }}$}

In this paper, I discuss and show the investigation techniques in ground water and the purpose of this research is to share with industry investigation techniques. In particular, the methodology, the findings and lessons learned. These techniques have applications at several sites, These investigations include the groundwater monitoring system, the radiological source term assessment and the atomospheric deposition modeling that include processes assessments, video inspections, and assessment of tritium migration through concrete, hydrostatic tracer tests, tritium/helium-3 residence times and tritium in soil. 